\title{
Üniversite Öğrencilerinin Zaman Yönetimi Becerilerinin; Depresyon Düzeyleri, Anksiyete ve Stres Seviyeleri ile İlişkisi
}

\section{The Relationship Between University Students' Time Management Skills; Depression Levels, Anxiety and Stress Levels}

\author{
iD Havva Tecer, ${ }^{1}$ iD Süleyman Dönmezler ${ }^{2}$, iD Habib Erensoy $^{3}$, iD Tonguç Demir Berkol² \\ ${ }^{1}$ Üsküdar Universitesi, Sosyal Bilimler Enstütüsü, Psikoloji Bölümü \\ ${ }^{2}$ Bakırköy Prof. Dr. Mazhar Osman Ruh Sağlığı ve Sinir Hastalıkları Eğitim ve Araştırma Hastanesi, Psikiyatri Kliniği. \\ ${ }^{3}$ Üsküdar Universitesi, Sosyal Bilimler Enstütüsü, Psikoloji Bölümü
}

\section{Öz}

Amaç: Üniversite öğrencilerinin akademik başarıları zamanı etkin kullanma becerileriyle oldukça ilişkilidir. Üniversite öğrencilerinin \%60 kadarı depresyon, anksiyete ve uyumsuzluk gibi psikolojik faktörlerden etkilenmektedir. Çalışmamızın amacı üniversite öğrencilerinin zaman yönetimi becerileri ile depresyon düzeyleri, anksiyete ve stres seviyeleri arasındaki ilișkiyi çeșitli boyutlara göre değerlendirmektir.

\begin{abstract}
Yöntem: Çalıșmamız 2018-2019 eğitim yılı, güz döneminde, Üsküdar Üniversitesi’nin çeșitli bölümlerinde okuyan 159 öğrenciyi zaman yönetimi becerileri özelinde; depresyon düzeyleri, anksiyete ve stres seviyelerine göre incelemektedir. Öğrencilere Zaman Yönetimi (ZYE) ve Depresyon-Anksiyete-Stres Ölçeği (DASS-42) envanterleri uygulanmış, elde edilen veriler öğrencilerin çeşitli demografik özelliklerine göre karşslaştırılmıştır.

Bulgular: Üniversite öğrencilerinin zaman yönetimi becerileri, cinsiyet, yaș ve akademik başarılarına göre anlamlı bir șekilde farklılaşmaktadır. Kız öğrencilerin erkek ögrencilere göre zamanı daha etkin kullandıkları tespit edilirken, zaman yönetiminin akademik başarı ile arasında güçlü ve pozitif yönlü bir ilişki bulunmuştur. Zaman yönetimi, yaşa göre de anlamlı bir şekilde farklılaşsa da bu ilişki tam doğrusal değildir. En düşük depresyon, anksiyete ve stres ortalamaları, genel not ortalaması 2 ile 3 arasında olan öğrencilerde gözlenmiştir. Öğrencilerin depresyon, anksiyete ve stres düzeylerinin hangi sınıfta olduklarına göre farklılık göstermediğini söyleyebiliriz. Yalnızca anksiyete düzeylerindeki fark \%10 anlamlılık düzeyinde anlamlıdır. En düşük kaygı ortalaması üçüncü sınıf öğrencilerine aitken en yüksek kaygı dördüncü sınıf ögrencilerindedir.
\end{abstract}

Sonuçlar: Öğrencilerin zaman yönetimi becerileri ile depresyon-anksiyete ve stres seviyeleri arasında negatif yönlü bir ilişki tespit edilmiştir. Son sınıf öğrencilerinde kaygının yüksek olması üniversite sürecinin bitip hayata atılmak ile ilgili olabilir. Kadınların zamanı etkin kullanabilme yetisinin toplumsal bir altyapısı olduğu düşünülebilir. Depresyon düzeyleri, anksiyete ya da stres seviyesi yüksek olan öğrencilerin zaman yönetimi becerileri düşüktür.

Anahtar kelimeler: Zaman Yönetimi, Depresyon, Anksiyete, Stres.

\section{Abstract}

Objective: The academic success of university students is highly related to their ability to use time effectively. The aim of our study is to evaluate the relationship between university students> time management skills and depression levels, anxiety and stress levels according to various dimensions.

Method: Our study covers 159 students studying in various departments of Üsküdar University in the fall semester of $2018-2019$ academic year. According to time management skills; depression, anxiety and stress levels was examined. Time Management and Depression-Anxiety-Stress Scale (DASS-42) inventories were applied to the students and the data obtained were compared according to the various demographic characteristics of the students.

Results: The time management skills of university students differ significantly based on their gender, age and academic achievement. While it was determined that female students use time more effectively than male students, a strong and positive relationship was found between time management and academic achievement. The lowest depression, anxiety, and stress averages were observed in students whose grade point average was between 2 and 3 . The lowest anxiety means belongs to third grade students, while the highest anxiety belongs to fourth grade students.

Conclusions: A negative correlation was found between students> time management skills and depression-anxiety and stress levels. The highest level of anxiety among senior students may be related to the completion of the university process and launching into life. It can be thought that the ability of women to use time effectively has a social infrastructure. Students with high levels of depression, anxiety or stress have low time management skills.

Keywords: Time Management, Depression, ,Anxiety, Stress.

Yazışma Adresi: Süleyman Dönmezler; Bakırköy Prof. Dr. Mazhar Osman Ruh Sağlığı ve Sinir Hastalıkları Eğitim ve Araştırma Hastanesi, Psikiyatri Kliniği. E-Posta: suleymandonmezler@gmail.com

Alınma Tarihi: 09.05.2020 / Kabul Tarihi: 10.07.2020 / Yayımlanma Tarihi: 20.09.2021

Üniversite Öğrencilerinde Zaman Yönetimi - Tecer ve ark. 


\section{Giriş}

Zaman yönetimi, kişisel tercihler, beğeniler, hedefler ve yaşam tarzları doğrultusunda mevcut zamanın planlanması anlamına gelir. Etkin zaman yönetimi kriteri sadece belirlenen hedeflere ulaşılmasını değil, aynı zamanda mümkün olan en kısa zamanda istenilenlerin elde edilmesini de amaçlar (1) ve bu noktada asıl olan mevcut zamanı en etkin ve verimli şekilde kullanmaktır (2). Zamanlarını etkin ve verimli bir şekilde kullanabilenler, belirli bir zaman diliminde tek bir konuya odaklanmayan; zamanlarını iş, özel yaşam ve kişisel ilgi alanları gibi çeşitli faaliyetler arasında dağıtabilen kişilerdir (3). Yetersiz zaman planlaması, akademik başarının kapsamını azaltır, diğer kişisel ve sosyal faaliyetler için yetersiz zaman tahsisine neden olarak bireysel memnuniyeti düşürür ve kişilerin stres seviyelerini artırır. Bu durum, karar verme, liderlik ve eleştirel düşünme gibi olumlu kişilik özelliklerinin kaybına ya da hiç kazanılamamasına yol açar (4). Smith'e (5) göre, bireylerin zamanla başa çıkma biçimleri, psikolojik olarak gergin mi yoksa depresif mi olacaklarını gösterir. Zamanlarını iyi organize edemeyenlerin stresi kaçınılmaz olarak deneyimledikleri ve gün içinde zamanlarının birçok işe yetmediğini düşünenlerin yaşadıkları problemlerin ana sebebi, zamanlarını nasıl kullanacaklarını ve yöneteceklerini bilmemeleridir.

Üniversite öğrencilerinin başarısı, zamanı doğru ve en verimli şekilde kullanma becerilerine bağlıdır. Nitekim zaman yönetimi ve akademik başarı arasında birçok çalışmada olumlu bir ilişki bulunmuştur $(6,7,8)$. Bu bulgulara dayanarak, bu çalışma Üniversite öğrencilerinin, zaman yönetimi becerileri ile yaş, cinsiyet ve kaygı düzeyleri gibi faktörler arasındaki ilişkiyi anlamaya ve böylece zaman yönetimi konusunda daha fazla öneride bulunmaya odaklanmıştır. Bunun yanı sira depresyon, stres ve kayg1 gibi durumların öğrencilerin zaman yönetimi becerilerini ne derecede etkilediği ya da çalışmanın ana odak noktasıdır.

Zaman yönetimi birçok alanda olduğu gibi üniversite öğrencilerinin eğitim hayatında da oldukça önemli bir konumda yer almaktadır. Üniversite hayatında zamanını iyi yöneten öğrencilerin hem akademik hem de sosyal alanlarda daha başarılı oldukları bir önceki bölümde vurgulanmıştır. Dolayısıyla söz konusu duruma olumlu ya da olumsuz yönde etki eden faktörler incelenmesi gereken konular arasında yer almaktadir.

Bu çalışmanın birincil amacı depresyon, anksiyete ve stres gibi hayatı birçok alanda olumsuz yönde etkileyen durumların üniversite öğrencilerinin zaman yönetimi becerilerini etkileyip etkilemediği araştırmak ve kayda değer ilişkilerin yönü ve şiddeti belirlemektir Sekonder amaç olarak zaman yönetimi becerisinin demografik değişkenlerle oluşturulan alt gruplardaki farklılıklarını araştırmaktır.

\section{Metot}

$\mathrm{Bu}$ çalışma, 2018-2019 eğitim yılı, güz döneminde, Üsküdar Üniversitesi'nin çeşitli bölümlerinde okuyan öğrencileri, zaman yönetimi becerileri özelinde, depresyon, anksiyete ve stres seviyelerine göre incelemektedir, ölçekler toplamda 159 öğrenciye uygulanmıştır.
Çalışma, ilgili envanterlerle elde edilen verilerin çeşitli istatistiksel yöntemlerle karşılaştırılmasına dayanmaktadır.

\section{Veri Toplama Araçları}

Zaman Yönetimi Envanteri: Britton ve Tesser (6) tarafindan geliştirilen ve Türkçe uyarlaması, güvenilirlik ve geçerlilik analizleri Alay ve Koçak (7) tarafından yapılan Zaman Yönetimi Envanteri (ZYE) birçok çalışmada kullanılmış, güvenilirlik ve geçerliliği oldukça yüksek bir envanterdir. Alay ve Koçak, orijinali 35 madde olan Zaman Yönetimi Envanterinin, Türk üniversite öğrencileri için üç alt ölçeğe sahip olduğunu göstermiştir. Bu üç alt ölçek Türk öğrenciler için toplam varyansın \% 34'ünü oluşturmakta iken orijinal çalışmada, üç alt ölçek toplam varyansın \% 36 olduğu bildirilmiştir.

Faktör 1, gün içinde veya hafta içinde kısa vadede planlama ve uzun vadede planlama ile ilgili maddeleri temsil eder. $\mathrm{Bu}$ alt boyuttan yüksek puan alan öğrenciler, zamanlarını iyi organize ettiklerini ve her şeyi göreceli olarak geniş bir zaman aralığında düşündüklerini bildirirler. Faktör 1>de kümelenmiş maddeler kısa ve uzun vadeli planlama ile ilgili olduğundan, bu faktör "Zaman planlama" olarak adlandırılmıştır. Faktör 2, doğada daha fazla tutum içeren maddeleri içermektedir. Bu faktörden yüksek puan alan öğrenciler, zamanlarının yapıcı bir şekilde kullanıldığını ve zamanlarının nasıl harcandığından kendilerinin sorumlu olduğunu belirtirler. $\mathrm{Bu}$ faktör "Zaman tutumları" olarak adlandırılmıştır ve orijinal çalışmaya paraleldir. Faktör 3, "zaman kaybı" olarak adlandırılan alışkanlıkların kullanımı ve kişisel zamanın boşa kullanımı ile ilgili kötü zamanlarla alakalı maddelere sahiptir. Zaman kaybı, öğrencilerin okul hedeflerine etkili bir şekilde ulaşmalarını engelleyen herhangi bir şeydir. Bu alt altta yüksek puan alan öğrenciler, zaman içindeki başarılarının düşük olması nedeniyle madde içindeki puanları tersine çevrilmiştir.

Depresyon-Anksiyete-Stres Ölçeği (DASS-42): Çalışmada, depresyon, anksiyete ve stres için Lovibond and Lovibond (9) tarafından geliştirilen ve Türkçe uyarlaması ile geçerlilik-güvenilirlik analizleri Bilgel ve Bayram (2010) tarafindan yapılan DASS-42 (Depresyon-Anksiyete-Stres Ölçeği) kullanılmıştır. Bilgel ve Bayram (10) DASS-42'nin Türkçe versiyonunun güvenilirliğini, yapısını ve yakınsak geçerliliğini incelemek amacıyla bir çalışma gerçekleştirmiştir. DASS-42'nin Türkçe versiyonu, geniş bir üniversite öğrencisi popülasyonuna $(\mathrm{n}=1102)$ demografik değişkenler açısından değişkenlik gösteren ve klinik olmayan bir örnekleme uygulanmıştır. Ölçeğin yakınsak geçerliliği, Hastane Anksiyete ve Depresyon Ölçeği'nin önceden doğrulanmış ve sık kullanılan Türkçe versiyonuyla ilişkilendirilerek incelenmiştir. Bulgular DASS'ın güvenilirliğinin mükemmel olduğunu ve ölçeğin yeterli yakınsak geçerliliğe sahip olduğunu göstermektedir. Sonuç olarak DASS-42'nin Türkçe versiyonu, değerlendirmeyi amaçladığ 1 yapıların güvenilir ve geçerli bir ölçüsüdür. Bu ölçek klinik olmayan popülasyonda depresyon, anksiyete ve stresi değerlendirmek için yararlı bulunmuştur.

Üniversite Öğrencilerinde Zaman Yönetimi - Tecer ve ark. 


\section{Veri Analiz Yöntemleri}

$\mathrm{Bu}$ çalışmanın ana odağ karşılaştırma istatistiklerine dayanmaktadır. Bu doğrultuda SPSS 25 programında, eşleştirilmiş ya da bağımsız örneklem t-testleri, ANOVA, Mann-Whitney ve Kruskal Wallis gibi karşıllaştırma yöntemlerinin yanı sıra, korelasyon ve regresyon analizi gibi metotlar kullanılmıştır. Bu yöntemlerle hem demografik verilere göre karşılaştırmalar yapılmış, hem de zaman yönetimi ile depresyonanksiyete-stres seviyeleri arasındaki korelasyon incelenmiştir. T-testi ve ANOVA grubun ortalamalarının birbirinden farklı olup olmadığını inceleyen parametrik testlerdir. Çalışmada verilerin bağımsız ve normal dağılım varsayımlarına uydukları kabul edilmiş, varyans homojenliği için ise Levene Testi sonuçlarına bakılmıştır. Eğer veriler Levene Testi'nden geçemezse, parametrik testlerin yanında parametrik olmayan testlerin sonuçları da (Mann-Whitney ve Kruskal Wallis) verilmiştir.

\section{Etik ve Çıkar Çatışması}

Bu çalışma Helsinki Deklerasyonu Prensiplerine uygun yapılmıştır. Bu çalışma için Üsküdar Üniversitesi Girişimsel Olmayan Araştırmalar Etik Kurulu Başkanlığından onay alınmıştır. Gönüllülük ilkesi ile yazılı ve sözlü bilgilendirme yapılarak onamları alınan katılımcılar tarafından formlar doldurularak veriler toplanmıştır. Yazarlar çıkar çatışması belirtmemektedirler.

\section{Bulgular}

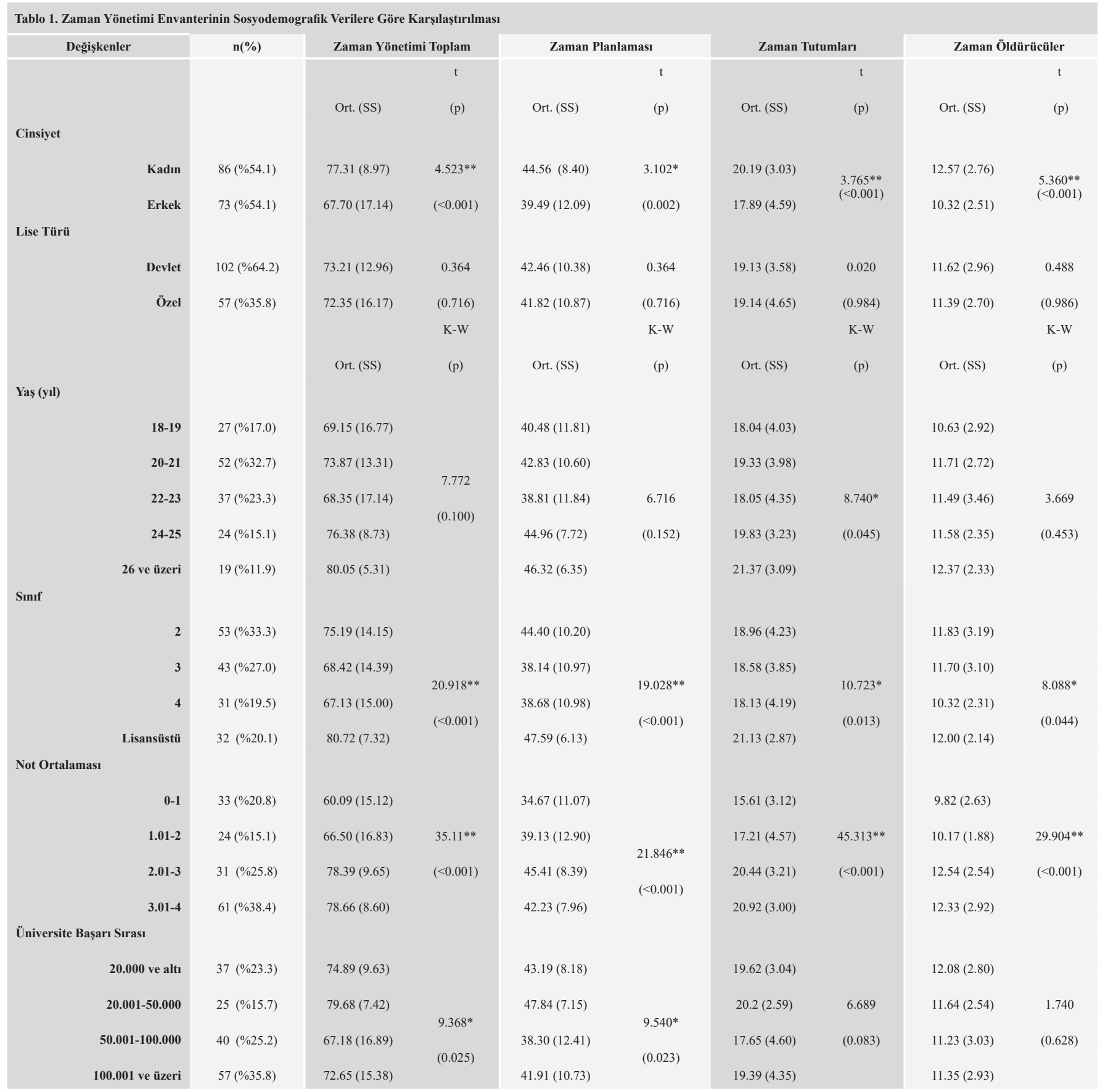




\begin{tabular}{|c|c|c|c|c|c|c|c|c|c|}
\hline \multicolumn{10}{|l|}{ Gelir Durumu } \\
\hline 2.000 TL ve altı & $47(\% 29.6)$ & $74.17(15.17)$ & 2.107 & $42.47(11.62)$ & 0.132 & $19.53(3.81)$ & 3.328 & $12.17(3.33)$ & 5.736 \\
\hline $2.001-5000 \mathrm{TL}$ & $83(\% 52.2)$ & 73.45 (12.58) & $(0.349)$ & 42.47 (9.37) & $(0.936)$ & $19.37(4.06)$ & $(0.189)$ & $11.6(2.42)$ & $(0.057)$ \\
\hline 5.001 TL ve üzeri & $29(\% 18.2)$ & $69.28(16.47)$ & & $41.17(12.06)$ & & $17.79(3.87)$ & & $10.31(2.92)$ & \\
\hline \multicolumn{10}{|l|}{ Barınma Türü } \\
\hline Yurt & $30(\% 18.9)$ & 66.67 (17.44) & & $38.8(12.49)$ & & $17.03(4.12)$ & & $10.93(3.61)$ & \\
\hline Tek Başına & $32(\% 20.1)$ & $64.66(15.69)$ & $17.408^{*}$ & $37.72(11.40)$ & \multirow{3}{*}{$\begin{array}{l}10.937 * \\
(0.012)\end{array}$} & $16.47(4.20)$ & $31.407^{* *}$ & $10.47(2.25)$ & $12.171^{*}$ \\
\hline Arkadaşlarla & $24(\% 15.1)$ & $76.13(10.75)$ & $(0.001)$ & $44.29(9.92)$ & & $20.42(1.93)$ & $(<0.001)$ & $11.42(3.04)$ & $(0.007)$ \\
\hline Aile ile & $73(\% 45.9)$ & $77.97(9.93)$ & & $44.95(8.39)$ & & $20.74(3.32)$ & & $12.29(2.52)$ & \\
\hline
\end{tabular}

Tablo 1'de Zaman Yönetimi envanteri sosyodemografik verilerle karşılaştırılmıştır. Cinsiyet ve lise bağımsız gruplar $t$ testi ile değerlendirilmiştir. Diğer değişkenlerin oluşturduğu alt gruplarda varyanslar homojen dağılmadığı için aradaki farklılıklar Kruskal Wallis testi ile değerlendirilmiştir. İstatistiksel olarak anlamlı saptanan farklılıklar tabloda işaretlenip p değeri ile birlikte verilmiştir.

Korelasyon analizlerine gelinecek olunursa;

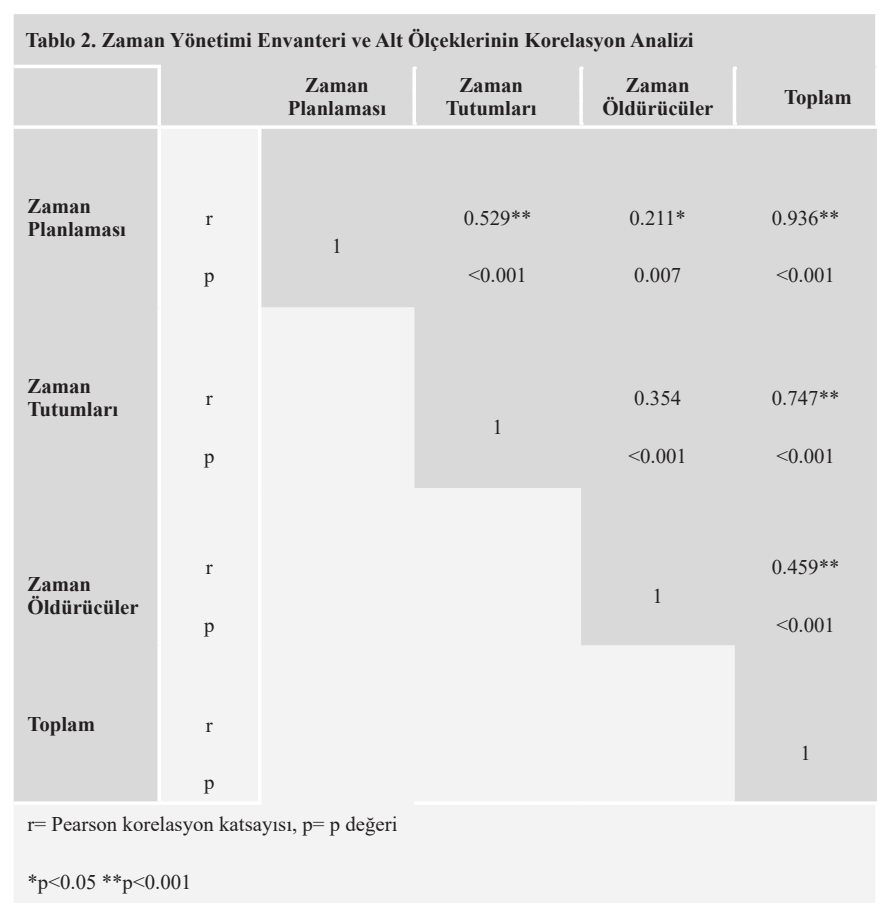

Tablo 2'de gösterilen sonuçlar ZYE'nin orijinal versiyonunda ve Türkçe uyarlamasında olduğu gibi alt ölçeklerin de birbirleriyle anlamlı bir ilişkiye sahip olduğunu göstermektedir. Zaman Yönetimi envanteri toplam puanı ile zaman planlaması alt ölçeği çok ileri derecede pozitif korelasyon göstermektedir. Zaman Yönetimi envanteri toplam puanı ile en az korelasyon ise zaman tutumları alt ölçeğine aittir. Aralarında en zayıf korelasyon olan iki alt ölçek zaman planlaması ve zaman öldürücülerdir.
Tablo 3; öğrencilerin depresyon, anksiyete ve stres seviyelerinin birbirleriyle olan ilişkisine dair korelasyon verilerine içermektedir. Depresyon ile Anksiyete arasındaki korelasyon \%86, Depresyon ile Stres arasındaki korelasyon \%81 ve Anksiyete ile Stres arasındaki korelasyon ise \%79'dur. Tüm korelasyonlar \%1 seviyede anlamlıdır. Daha önce literatür başlıklarında da belirtildiği gibi bu üç gösterge birbiriyle oldukça güçlü bir ilişkiye sahiptir.

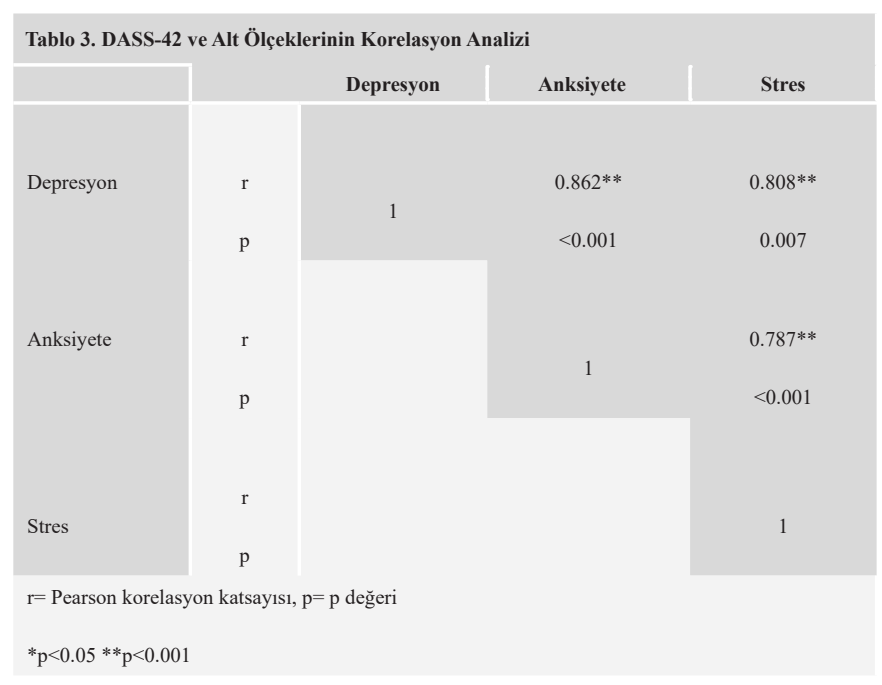

Tablo 4'de ise ZYE ile DASS-42 ölçekleri arasındaki korelasyon analizine yer verilmiştir. Beklenildiği gibi zaman yönetimi becerileri ile depresyon-anksiyete ve stres arasında negatif yönlü bir ilişki mevcuttur. Tüm değerler $\% 1$ seviyede anlamlıdır. $\mathrm{Bu}$ sonuçlar göstermektedir ki öğrencilerin depresyon, anksiyete ve stres seviyeleri, birlikte ya da ayrı ayrı arttıkça zaman yönetimi becerileri azalmaktadır. Ya da tam tersi durumda zaman yönetimi becerileri artmaktadır. 


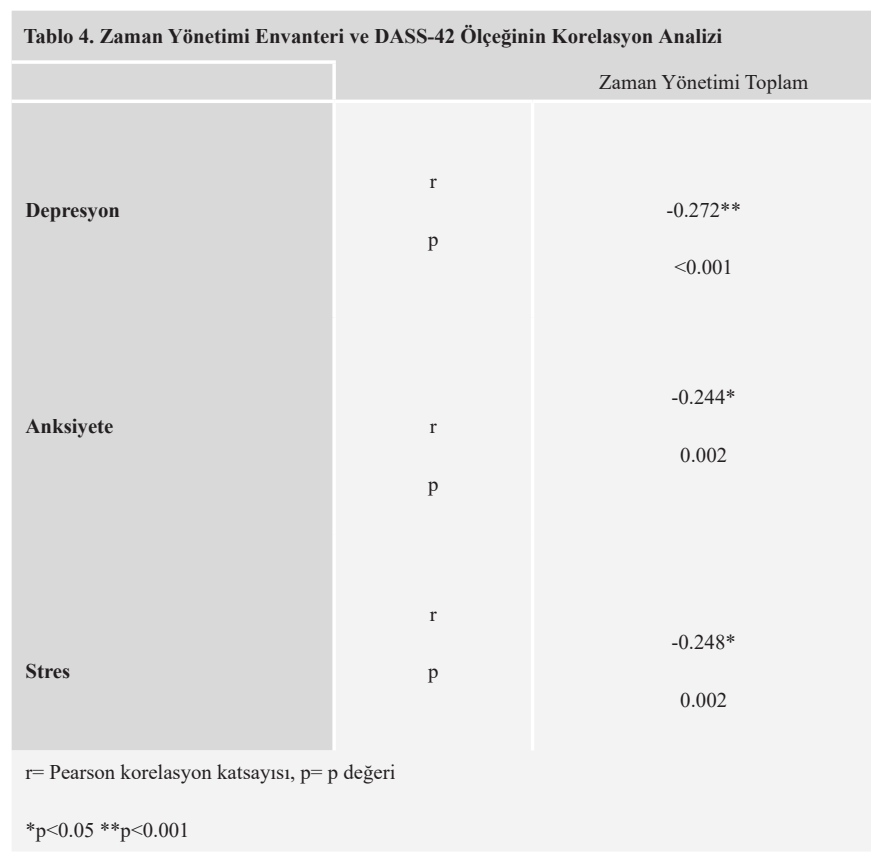

\section{Tartışma}

Kadın öğrencilerin zaman yönetimi skorları erkek öğrencilere göre anlamlı bir şekilde yüksek bulunmuştur. Bunun toplumsal bir alt yapısı olduğu, yetiştirilme tarzıyla ilişkili olabileceği düşünülmüştür. Farklı yaş grupları farklı zaman yönetimi becerilerine sahiptir. Puanların yaşla birlikte arttığı söylenebilir. Öğrencilerin yaşları arttıkça, deneyimleriyle doğrultusunda zamanı daha iyi yönetebilecekleri söylenebilir. Öğrencilerin zaman yönetimi puanları kaçıncı sınıfta olduklarına göre anlamlı bir şekilde farklılaşmaktadır. Öğrenciler bir üst sınıfa geçtikçe zamanı daha iyi kullanabileceklerdir. Zaman yönetimi ve not ortalaması arasında anlamlı bir ilişki bulunmaktadır. Not ortalaması daha yüksek olanlarda daha iyi zaman yönetimi beklenen bir düşüncedir ve çalışmamızda bu düşüncenin doğruluğu istatistiksel olarak gösterilmiştir. Çalışmada ele alınan popülasyonda zaman yönetimi puanları yüksek olan öğrencilerin not ortalamalarının da yüksek olduğu tespit edilmiştir. Benzer şekilde üniversite sınavı başarı sıralaması da zaman yönetiminde öğrencilerin farklılaşma gösterdiği bir değişkendir. Öğrencilerin zaman yönetimi becerileri ile aylık gelirleri arasında anlamlı bir ilişki tespit edilememiştir.

Üniversite öğrencilerinin akademik başarıları zamanı etkin kullanma becerileriyle oldukça ilişkilidir. Çünkü zaman yönetimi birçok alanda olduğu gibi üniversite öğrencilerinin eğitim hayatında da oldukça önemli bir konumda yer almaktadır. Üniversite hayatında zamanını iyi yöneten öğrencilerin hem akademik hem de sosyal alanlarda daha başarılı oldukları bir önceki bölümde vurgulanmıştır. Dolayısıyla söz konusu duruma olumlu ya da olumsuz yönde etki eden faktörler incelenmesi gereken konular arasında yer almaktadır. Üniversite öğrencilerinin \%60 kadarı depresyon, anksiyete ve uyumsuzluk gibi psikolojik faktörlerden oldukça etkilenmektedir. Dolayısıyla bu olumsuz etkiler, öğrencilerin zaman yönetimi tamamiyle yerle bir ederek kendilerini bir çıkmaza sürükleyebilir (11).
Öğrencilerin zaman yönetimi becerileri ile akademik başarıları arasında bir ilişki olup olmadığını belirlemek için geçmişte çeşitli çalışmalar yapılmıştır $(12,13)$. Her üç çalışma da zaman yönetimi becerileri ile öğrencilerin akademik başarıları arasında anlamlı ilişkiler tespit etmişlerdir. Bunun yanı sıra Barling et al. akademi ve işle ilgili performans sonuçları arasında zaman yönetimi açısından farklılık olduğunu belirtmişler; okul notları ve ders çalışma alışkanlıklarının zaman yönetiminden olumlu yönde etkilendiğini ortaya koymuşlardır (14). Yukarıdaki bulgular bu çalışmayla paraleldir.

Çalışmada incelenen bir başka envanter DASS-42'dir. Bu envanter depresyon, anksiyete ve stresi tek bir ölçeğin alt grupları olarak değerlendirmektedir ve literatürde birçok çalışmada kullanılmıştır. DASS-42 ölçeğinin psikometrik araştırmasının yapıldığ çalışmada ortalama kaygı ve stres puanları kadınlarda erkeklere göre anlamlı derecede yüksek bulunmuşken, ortalama depresyon puanları anlamlı olarak farklı bulunmamıştır (10). Kadın ve erkek öğrencilerin depresyon, anksiyete ve stres seviyeleri arasında anlamlı bir farklılık bulunmamaktadır. Anksiyete ve stres yönüyle bu bulgular Bilgel ve Bayram (10) ile çelişse de genel itibariyle Lovibond ve Lovibond (9) ile uyumludur.

Literatürde bir grup çalışmada, zaman yönetiminin depresyon ve stresle ilişkisinin araştırılmıştır $(15,16,17,18,19,20)$. Bu çalışmaların ortak sonucu zaman yönetiminin depresyon, anksiyete ve stres ile negatif yönlü bir ilişkiye sahip olduğudur. Bu tezde elde edilen bulgular belirtilen çalışmalarla uyumludur. Öğrencilerin zaman yönetimi puanları ile DASS-42 puanları arasındaki korelasyon negatif yöndedir ve istatistiksel olarak anlamlı olduğu için çalışmamızın örnekleminde saptadığımız ilişki çalışma evreni hakkında çıkarımda bulunmamıza yardımcı olabilir.

Çalışmamızın çeşitli kısıtlılıkları vardır. Çalışmanın bir kısıtı tek bir üniversite ile sınırlı olmasıdır. Sonuçlar vakıf üniversitesi ile devlet üniversitesi öğrencilerinde farklılık gösterebileceğinden dolayı bu nokta başka çalışmaların konusu olabilir. Çalışmanın ikinci sınırlılığı ise kullanılan ölçeklerle ilgilidir. Bu tezin odak noktası ve diğer alt başlıklarıyla cevap aranan sorular, DASS-42 ve ZYE envanterlerinin ölçme kabiliyetleriyle sınırlıdır. $\mathrm{Bu}$ sebeple zaman yönetimi ve depresyon-anksiyete-stres seviyeleri arasındaki ilişki, farklı envanterler kullanılarak da değerlendirilirse bulgular güçlendirilebilir. Bir başka kısıt ise araştırmaya birinci sınıf üniversite öğrencilerinin dahil edilmemesidir. Demografik bilgi formunda yer alan sorulardan birisi not ortalaması ile ilgilidir ve birinci sınıf öğrencilerinin not ortalamaları henüz dikkate değer bir şekilde belirlenmediğinden örnekleme dahil edilmemişlerdir. Çalışmada düşünülebilecek son kısıt ise demografik bilgi formu özelinde olabilir. İleri çalışmalar daha detaylı demografik sorularla dizayn edilebilir. Her ne kadar yukarıdaki kısıtlar ve varsayımlar bir kısıtlılık oluştursa da üniversite öğrencilerinde zaman yönetimi, depresyon ve anksiyete ilişkisi literatürde doğrudan bir incelemeye tabi tutulduğuna rastlanmamıştır. $\mathrm{Bu}$ yönüyle çalışmamızın alanyazına katkıda bulunabileceği düşünülmüştür. 
Sonuç olarak; $\mathrm{Bu}$ çalışmada, üniversite öğrencilerinin zaman yönetimi becerileri Zaman Yönetimi Envanteri (ZYE) depresyonanksiyete-stres seviyeleri Depresyon-Anksiyete-Stres Ölçeği (DASS42) ile ölçülmüştür. Bu envanterlerle elde edilen veriler öğrencilerin çeşitli demografik özelliklerine göre karşılaştırılmıştır. Bulgulara göre üniversite öğrencilerinin zaman yönetimi becerileri, cinsiyet, yaş, akademik başarı ve barınma tercihlerine göre anlamlı bir şekilde farklılaşmaktadır. Kız öğrencilerin erkek öğrencilere göre zamanı daha etkin kullandıkları tespit edilirken, zaman yönetiminin akademik başarı ile arasında güçlü ve pozitif yönlü bir ilişki tespit edilmiştir. Zaman yönetimi, yaşa göre de anlamlı bir şekilde farklılaşsa da bu ilişki tam doğrusal değildir. Öğrencilerin gelir seviyelerinin ise zaman yönetimlerini etkilemedikleri bulunmuştur.

Çalışmada DASS-42 ile elde edilen sonuçlar ise depresyon, anksiyete ve stresin cinsiyetten bağımsız olduğunu ortaya koymuştur. Benzer şekilde yaş ve barınma tercihleri de öğrencilerin depresyonanksiyete-stres düzeylerini etkilememektedir. Fakat DASS-42 puanları öğrencilerin akademik başarılarına göre anlamlı bir şekilde farklılaşmaktadır.

Son olarak literatürle uyumlu olacak şekilde, öğrencilerin zaman yönetimi becerileri ile depresyon-anksiyete ve stres seviyeleri arasında negatif yönlü bir ilişki tespit edilmiştir. Bir başka ifadeyle depresyon, anksiyete ya da stres seviyesi yüksek olan öğrencilerin zaman yönetimi becerileri düşüktür.

\section{Kaynaklar}

1.Eldeleklioğlu J, Özkılıc R. The effect of critical thinking education on critical thinking skills of psychological guidance and counseling students. Türk Psikolojik Danışma ve Rehberlik Dergisi Arşiv. 2008;3:29.

2.Karaoğlan AD. Üst düzey yöneticilerin zaman yönetimi. Yayınlanmamış Yüksek Lisans Tezi. Balıkesir: Balıkesir Üniversitesi FBE. 2006.

3.Sayan İ. Yönetici hemşirelerde zaman yönetimi. Marmara Üniversitesi Tez Koleksiyonu. 2005 .

4.Campbell RL, Svenson LW. Perceived level of stress among university undergraduate students in Edmonton, Canada. Perceptual and Motor Skills. 1992;75:552-54.

5.Smith, J. Daha İyi Nasıl Zaman Yönetimi. (Çev. Ali Çimen). İstanbul, Tima Yayınları. 1998 .

6.Britton BK, Tesser A. Effects of time-management practices on college grades, Journal of Educational Psychology. 1991;83:405-15.

7.Alay S, Kocak S. Validity and reliability of time management questionnaire. Hacettepe Üniversitesi Eğitim Fakültesi Dergisi, 2002;22.

8.Demirtaş H, Özer N. Öğretmen Adaylarının Zaman Yönetimi Becerileri İle Akademik Başarısı Arasındaki İlişskisi. Eğitimde Politika Analizleri ve Stratejik Araştırmalar Dergisi. 2007;2(1).

9.Lovibond PF, Lovibond SH. The structure of negative emotional states: Comparison of the Depression Anxiety Stress Scales (DASS) with the Beck Depression and Anxiety Inventories. Behaviour Research and Therapy. 1995;33(3):335-43.

10.Bilgel N, Bayram N. Turkish Version of the Depression Anxiety Stress Scale (DASS42): Psychometric Properties. Archives of Neuropsychiatry/Noropsikiyatri Arsivi, 2010;47(2)

11.Kesler SR. (2007). The effects of organizational structure on faculty job performance, job satisfaction, and counterproductive work behavior (Unpublished doctoral dissertation). University of South, Florida-USA. 2007.
12.Cemaloğlu N, Filiz S. (2010). The relation between time management skills and academic achievement of potential teachers. Educational Research Quarterly. 2010;33(4):3-23.

13.Hamzah AR, Lucky EOI, Joarder MHR. Time management, external motivation, and students' academic performance: Evidence from a Malaysian Public University. Asian Social Science, 2014;10(13):55.

14.Barling J, Kelloway EK, Cheung D. Time management and achievement striving interact to predict car sale performance. Journal of Applied Psychology. 1996;81:821-26.

15.Adams GA, Jex SM. Confirmatory factor analysis of the time management behaviour scale. Psychological Reports. 1997;80:225.

16.Davis MA. Time and the nursing home assistant: relations among time management, perceived control over time, and work-related outcomes. paper presented at the Academy of Management:Toronto. 2000.

17.Jex JM, Elacqua TC. Time management as a moderator of relations between stressors and employee strain. Work \& Stress. 1999;13:182-91

18.Francis-Smythe JA, Robertson IT. Time-related individual differences. Time \& Society. 1999;8:273-92

19.Macan TH. Time management: test of a process model. Journal of Applied Psychology $1994 ; 79: 381-91$

20.Bond M, Feather N. Some correlates of structure and purpose in the use of time. Journal of Personality and Social Psychology. 1988;55:321-29 